\title{
Picture Word Inductive Model: Its Effectiveness to Teach Writing Viewed from Students' Interest
}

Rahayu Meliasari, Ngadiso, Sri Marmanto

Master Degree of English Education Department Universitas Sebelas Maret, Surakarta, Indonesia

Email: amuhtia@student.uns.ac.id

How to cite this paper: Meliasari, R., Ngadiso, N., \& Marmanto, S. (2018). The Picture Word Inductive Model: Its Effectiveness to Teach Writing Viewed from Students' Interest. International Journal of Language Teaching and Education, 2(3), 248-258. https://doi.org/10.22437/ijolte.v2i3.5697

Accepted: October 18, 2018

Published: November 30, 2018

Copyright (C) International Journal o Language Teaching and Education.

This work is licensed under the Creative Commons Attribution InternationalLicense (CC BY 4.0).

http://creativecommons.org/licenses/by/4 $.0 /$

(c) (i)

\section{Abstract}

Picture Word Inductive Model is an inquiry-oriented strategy for teaching writing that uses picture containing familiar objects to fully lead students into inquiring about words, adding words to their writing, and ultimately developing the title, sentences, and paragraphs about their picture. This experimental study aimed to find out the effectiveness of PWIM to teach writing viewed from students' interest in the eighth grade of MTs. ASWAJA Pontianak. Sampling technique was through cluster random sampling resulting 2 classes which consist of 26 students of each class contributed to the study. Technique of data collection encompassed writing test and questionnaire. The data were analyzed by using 2x2 Multifactor Analysis of Variance (ANOVA) and Tukey's HSD Test. The result revealed that: (1) Picture Word Inductive Model (PWIM) is more effective than Controlled-Writing Strategy (CWS) to teach writing; (2) students having high interest have better writing skill than those having low interest. (3) there is an interaction between teaching strategies and the level of interest on students' writing skill.

\section{SubjectAreas}

Writing skill

\section{Keywords}

CWS, PWIM, students' interest, writing skill.

\section{Introduction}

Writing skill is postulated to be essential to proficient English learners. As the regulation implies that education is not only a matter of developing students' knowledge but also advancing skills and values; therefore, the students are expected to be able to considerably master four skills in learning English: listening, reading, speaking, and writing skills. Among those skills, they are naturally connected, and they share equal values with each other. However, partly because of the nature in the writing process, the teaching of writing skill demands extra attempts for teachers to reinforce students in writing activities. Writing is regarded as the most difficult skill for EFL students to master for it has complexities starting from brainstorming the ideas and organizing them into a readable text (Richard and Renandya, 2002, p. 303). Very often, most of 
the students put off doing until the last minute of writing.

In Indonesia, particularly in Junior High School stage, the basic competency that should be achieved in the writing English subject is that the students could develop and produce written simple functional text. However, although the students are only required to compose simple text, the result is far from what is being expected. Only a few students are happy to get involved in writing activities, but most of them are less keen. This unwillingness may derive from anxieties they have about the handwriting, their spelling, or their ability to construct sentences and paragraphs. If these insecurities are reinforced, then the students' attitude toward writing is likely to become more and more negative. As a result, their scores of writing are considerably low. Another noticeable problem is that students were very often asked to write about subjects and typical of novices in any subject areas that are unfamiliar to them. As the result, their understanding as they write tends to be incomplete.

Having the facts in mind, the teachers must be able to create a situation that provides opportunities and stimulates the students especially to be interested in writing. PWIM is an inquiry-oriented strategy for teaching beginning reading and writing that uses pictures containing familiar objects. The word inductive here means that it involves the process in which the students seek patterns and use them to identify their broader meaning and significant. Joyce \& Calhoun (2009) asserted that the Picture Word Inductive Model (PWIM) is a teacher-facilitated process, in which teachers lead children to discover words from a picture, increase the number of words in their sight-reading and writing vocabularies, formulate phonetic and structural principles, and finally apply observation and logical thinking analysis to their writing. This strategy is used to guide the students to develop their idea during the initial process of writing. Moreover, it also improves their vocabulary, grammatical, phonetic, mechanic, and spelling in writing text. In addition, Picture Word Inductive Model (PWIM) is a is an effective strategy for teachers which can be used with whole class, small groups, pairs, or individually involving basic moves from identifying the pictures, look for new words, hear the new word pronounced correctly, and watch the teacher model how to use the vocabulary on a variety of levels (McDonald, 2010; Wood \&Tinajero, 2002; Calhoun, 1999).

Even though teachers need to implement intriguing strategies to enhance students during the lesson, there is also a non-technical aspect that probably influences students' ability in writing. Students' interest is supposed to be one of the important elements in determining the success of writing class. The connection that exists between students and their interest in learning itself is enormously interrelated. According to Zhao (2014) interest is a kind of emotion arousal status and it tends to make people know things and love some activities. Similarly, Hurlock (1978) stating that interest is where the driving motivation comes from. This motivation drives students to do what they want to do when they are free to choose.

A piece of evidence leads the researcher to be interested in investigating whether 
PWIM is more effective than CWS to teach writing, revealing whether students having high interest have better writing skill than those having low interest, and revealing there is an interaction between teaching strategies and the level of interest on students' writing skill.

\section{Literature Review}

\subsection{Teaching Writing}

Teaching is the process of facilitating learning, enabling students to learn, and setting the conditions for learning (Brown, 2001). Teaching is showing or helping learners to grow in their knowledge, giving instructions, guiding in the study to improve their understanding. By referring to this, it is obvious that teaching writing is a work of the teacher in using one or more approaches to teach writing. Nevertheless, for many years the teaching of writing is only emphasized on the product of writing not the process (Harmer, 2004). The students were directed to what rather than how they produce a text. In fact, research result shown by Bayraktar (2012) pinpointed that a better understanding of writing processes leads to a successful writing. Hence, the teachers should consider appropriate strategies in teaching writing to emphasize on its process. They are the way to get the students to plan, the way to encourage them to draft, reflect and revise and the way to respond to the students' writing.

\subsection{Picture Word Inductive Model}

Basically, Picture Word Inductive Model (PWIM) is a strategy which uses the advantage of the picture as the learning media in teaching and learning process. According to Calhoun (1999, p. 21) PWIM is an inquiry-oriented language arts strategy that uses pictures containing familiar objects and actions to elicit words from children's listening and speaking vocabularies. This is based on the idea that model of teaching that uses picture and words can stimulate students' thinking inductively, from specific thinking (see the pictures and words) into general thinking (make the words that available become paragraph). PWIM is a strategy used with a whole class, small groups, pairs, or individually to lead students into inquiring about words and adding them vocabularies, discovering phonetic and structural principles, and engaging in other reading and writing activities (Wood \&Tinajero, 2002).

PWIM is a process of teaching language involving basic moves from identifying the pictures, looking for new words, hearing the new word pronounced correctly, and watching the teacher model how to use the vocabulary on a variety of levels. Thus, this is an effective strategy for all ages of learners for learning a second language because students have an opportunity to learn from authentic materials (McDonald, 2010). In a more specific way, there are sorts of procedures in implementing picture word inductive model in the classroom. In the first step, the teacher selects the picture for the learners. Secondly, asking the students to identify what they see in the picture. 
The third step, teacher labels the picture by drawing a line from the identified object or area, say the word, write the word, ask students to spell the word aloud and then to pronounce it. Soon after that, the students are asked to find as many words as possible to develop their ideas. The next step is leading the students into creating a title for the picture word chart. Then, the students are asked to create sentences using the words they gain from the picture word chart. After it has been accomplished, teacher asks students to arrange the sentences into a good paragraph. Ultimately, the teacher asks the students to read and review their paragraph to make it more complete and good.

\subsection{Controlled-Writing Strategy}

One of the conventional teaching strategies quite widely known and mostly used by the teacher for many years is Controlled-Writing Strategy (CWS). Controlled writing is a practical strategy for helping students put words down on paper by reinforcing grammar, vocabulary, and syntax in context (Silva, 1990; Raimes, 1983). It means that when the students write the paragraph, they are using the conventions of written English, such as indentation, punctuation, and connecting words, and spelling. With this controlled composition, it is relatively easy for students to write and yet avoid errors, which make errors correction easily.

Another idea of controlled writing is stated by Brown (2004: 225), that controlledwriting may also think as form-focused writing or grammar writing. A good deal writing in this level is display writing as opposed to real writing: students produce language to display their competence in grammar, vocabulary, or sentence formation, and not necessary to convey meaning for an authentic purpose. The instructional sequences of activity in CWS remain traditional ways. Taylor (1981) suggested that when implementing controlled writing strategy, the teacher should: (1) give modeling to students. At this stage, the teacher gives a sample text for the students; (2) ask student to read the text; (3) ask student to discuss or to brainstorm, at this stage, students are asked to make generalization and to see connections and relationships among their observation, thought, and facts; (4) ask the students work individually to write a paragraph about the topic; (5) ask the students discuss the paragraph that has been made.

\subsection{The Nature of Students' Interest}

It is inevitable that students' interest holds an enormous power in the success of learning. Several researches have been carried out concerning with students' interest in learning and there are some definitions about interest drawn from some experts. Interest and goals are two pivotal factor that cannot be separated to promote students' engagement and outcomes in learning (Chen \& Ennis, 2004; Chen \&Shen, 2004; Chen, 2001; Hidi\&Harackiewicz, 2000). Elliot (2000, p. 349) asserted that interest is a typical character that is continually showed by a relationship between a person and an activity or object. It means that when the activity fits the 
best with the students' preference, they will manifest attention, extra effort and active involvement during the lesson; as a result, their academic performance is improved. Another view is from Zhao (2014) asserting that interest is a kind of emotion arousal status and it tends to make people eager to know things and be passionate about some activities. It means interest makes the students capable of achieving the learning goal, especially when there is an interest in learning about something. When the students become interested in learning subject, they are eager to actively participate in, and are willing to explore as well as develop new abilities.

\section{Method of Research}

The key assumption of quantitative studies is the researchers advance the relationship among variables and pose this in terms of questions or hypotheses (Philips and Burbules, 2000). Regarding the focus of this study, the researcher employs experimental study. In this study, the researcher used $2 \times 2$ factorial design for the sake of efficiency, by technique of multifactor analysis of variance (ANOVA). It is the simplest form of factorial design. Gall, Gall, \& Borg (2007) posited that the expression 2 x 2 means two variations of one factor (A1 and A2) and two variations of another factor (B1 and B2) are manipulated at the same time. Cohen, Manion, and Marrison (2007) posited similar idea that a factorial design is useful for examining interaction effects.

In the post-test only design, the two groups of the subjects are first assigned to the different treatments or control conditions. The experimental group will be taught by using Picture Word Inductive Model (PWIM), while the control group will be taught by using Controlled-Writing Strategy (CWS). At the end of the treatments, both experimental and control groups will be given post-tests in the form of written test.

The subject of this research was addressed by using cluster random sampling. There were two classes who were officially enrolled in this study, consisting of 26 students of each class. The data were obtained from writing test and questionnaire. The form of the test is essay. To test writing skill, there are five main components that need to be considered, they are content, organization, vocabulary, grammar, and mechanics. Regarding the data from the questionnaire, it is categorized into four categories adapted from Likert Scale: strongly agree, agree, disagree, strongly disagree to reveal students' level of interest. By using questionnaire, the researcher will classify the students concerning only into two: high interest level and low interest level.

About data analysis, it is done using descriptive and inferential analysis. First and foremost, the data were analyzed using descriptive analysis to know the mean, median, mode, standard deviation, histogram, and polygon of the students' writing score. Meanwhile, the use of inferential statistics was to test the research hypothesis. Before doing further analysis of 2x2 ANOVA, the writer employed a prerequisite test, in which normality and homogeneity tests were assigned previously. As the result of ANOVA revealed that there is an interaction; therefore, the analysis was continued by 
using Tukey's HSD Test.

\section{Research Finding and Discussion}

\subsection{Finding}

The distribution of data in this research is classified into eight groups: (1) the description of writing score of experimental class taught by using Picture Word Inductive Model (PWIM) (A1); (2) the description of writing score of control class taught by using Controlled-Writing Strategy (CWS) (A2); (3) the description of writing score of students having high interest (B1); (4) the description of writing score of students having low interest (B2); (5) the description of writing score of students having high interest taught by using Picture Word Inductive Model (PWIM) (A1B1); (6) the description of writing score of students having low interest taught by using Picture Word Inductive Model (PWIM) (A1B2); (7) the description of writing score of students having high interest taught by using Controlled-Writing Strategy (CWS) (A2B1); (8) the description of writing score of students having low interest taught by using Controlled-Writing Strategy (CWS) (A2B2).

Admittedly, the overall values of Lo (Lobtain) is lower than Lt (Ltable), which means that the overall datasets were in normal distribution. The entire samples based on both teaching strategies and interest levels were in normal distribution. The following table depicts the summary of normality using Lilliefors test:

Table 1. The Summary of Normality Test

\begin{tabular}{lccc}
\hline \multicolumn{1}{c}{ Data } & $\mathrm{L}_{0}$ & $\mathrm{~L}_{\mathrm{t}}$ & Description \\
\hline $\begin{array}{l}\text { The writing scores of the students taught by using } \\
\text { PWIM }\left(\mathrm{A}_{1}\right)\end{array}$ & 0.1274 & 0.1738 & Normal \\
\hline $\begin{array}{l}\text { The writing scores of the students taught by using CWS } \\
\left(\mathrm{A}_{2}\right)\end{array}$ & 0.1017 & 0.1738 & Normal \\
\hline $\begin{array}{l}\text { The writing scores of the students having high interest } \\
\left(\mathrm{B}_{1}\right)\end{array}$ & 0.1711 & 0.1738 & Normal \\
\hline $\begin{array}{l}\text { The writing scores of the students having low interest } \\
\text { (B2) }\end{array}$ & 0.1060 & 0.1738 & Normal \\
\hline $\begin{array}{l}\text { The writing scores of the students having high interest } \\
\text { taught by using PWIM }\left(\mathrm{A}_{1} \mathrm{~B}_{1}\right)\end{array}$ & 0.2349 & 0.2457 & Normal \\
\hline $\begin{array}{l}\text { The writing scores of the students having low interest } \\
\text { taught by using PWIM }\left(\mathrm{A}_{1} \mathrm{~B}_{2}\right)\end{array}$ & 0.1632 & 0.2457 & Normal \\
\hline $\begin{array}{l}\text { The writing scores of the students having high interest } \\
\text { taught by using CWS }\left(\mathrm{A}_{2} \mathrm{~B}_{1}\right)\end{array}$ & 0.1132 & 0.2457 & Normal \\
\hline $\begin{array}{l}\text { The writing scores of the students having low interest } \\
\text { taught by using CWS }\left(\mathrm{A}_{2} \mathrm{~B}_{2}\right)\end{array}$ & 0.1475 & 0.2457 & Normal \\
\hline
\end{tabular}

Further analysis was homogeneity test. By referring to the computation result, the value of $\chi_{0}{ }^{2}$ is 0.8583 . Based on the Chi-Square distribution table, the value of $\chi_{\mathrm{t}^{2}(1-\alpha)(\mathrm{k}-}$ 1) or $\chi_{t^{2}(0.95)(3)}$ is 7.81. Hence, it can be said that the data are homogenous because $\chi_{0}{ }^{2}$ $<\mathrm{t}^{2}(0.8583<7.81)$. Once normality and homogeneity test were accomplished, the next step was Multifactor Analysis of Variance (ANOVA) $2 \times 2$. An analysis of variance (ANOVA) is administered to determine whether the differences between mean scores are statistically different. In this way, theoretically $\mathrm{H}_{\mathrm{o}}$ (null hypotheses) is accepted if 
$F_{o}\left(F_{o b t a i n}\right)$ is lower than or the same as $F_{t}\left(F_{\text {table }}\right)$ or $\left(F_{0} \leq F_{t}\right)$. Conversely, $H_{o}$ (null hypotheses $)$ is rejected if $\mathrm{F}_{\mathrm{o}}\left(\mathrm{F}_{\text {obtain }}\right)$ is higher than $\mathrm{F}_{\mathrm{t}}\left(\mathrm{F}_{\text {table }}\right)$ or $\left(\mathrm{F}_{\mathrm{o}}>\mathrm{F}_{\mathrm{t}}\right)$ which means that there is a significance difference. The summary of ANOVA $2 \times 2$ is described as follows:

Table 2. The Mean Score

\begin{tabular}{cccc}
\hline \multirow{2}{*}{ Interest $(\mathrm{B})$} & \multicolumn{2}{c}{ Teaching Strategy $(\mathrm{A})$} & \multirow{2}{*}{ Total } \\
\cline { 2 - 3 } & PWIM $\left(\mathrm{A}_{1}\right)$ & CWS(A $)$ & \\
\hline High Interest $\left(\mathrm{B}_{1}\right)$ & 81.85 & 75.69 & 78.77 \\
\hline Low Interest $\left(\mathrm{B}_{2}\right)$ & 74.46 & 74.62 & 74.54 \\
\hline Total & 78.15 & 75.15 & 76.65 \\
\hline
\end{tabular}

Table 3. The Summary of $2 \times 2$ Multifactor Analysis of Variance (ANOVA)

\begin{tabular}{cccccc}
\hline Source of Variance & SS & df & MS & $\mathrm{F}_{0}$ & $\mathrm{~F}_{\mathrm{t}(0,05)}$ \\
& & & & & 4.08 \\
\hline Between Columns & 117.00 & 1 & 117.00 & 4.476 & \\
\hline Between Rows & 232.69 & 1 & 232.69 & 8.901 & \\
\hline Interaction & 129.31 & 1 & 129.31 & 4.947 & \\
\hline Between Group & 479.00 & 3 & 159.67 & & \\
\hline Within Group & 1254.77 & 48 & 26.14 & \\
\hline Total & 1733.77 & 51 & & \\
\hline
\end{tabular}

Referring to the table, the interpretations are:

a) Following the result revealed on the above table, the value of $F_{0}(4.476)$ is compared to the $\mathrm{F}_{\text {table }}$ in which the value of $\mathrm{F}_{\text {table }}$ with $\mathrm{df}_{\text {numerator }}(1)$ and $\mathrm{df}_{\text {denominator }}$ (48) at the level of significance $=0.05$ is 4.08 . Obviously, the table depicts that the value of $F_{o}$ (4.476) is higher than $F_{t}(.05)$ (4.08). Hence, Ho is rejected and the difference between columns is significant. Turning to the table of mean score, it shows that the mean score of the students who were taught by using PWIM (78.15) is higher than the mean scores of the students taught by using CWS (75.15). It can be inferred that picture word inductive model is more effective than controlled-writing strategy to teach writing.

b) Based on the computing result, the value of $F_{0}(8.901)$ is statistically different from $F_{\text {table }}$ 4.08. It means that Ho is rejected and the difference between rows is significant. To put more simply, students who have high interest significantly different from those who have low interest. Regarding the mean score, students having high interest achieved higher mean score (78.77) compared to those having low interest (74.54). All in all, students who have high interest have better writing skill than those who have low interest.

c) By referring to the result of ANOVA, the value of interaction $\mathrm{F}_{\mathrm{o}}$ columns by rows (4.947) is higher than $F_{t}$ at the level of significance $=0.05$ (4.08). It can be inferred that $\mathrm{H}_{\mathrm{o}}$ is rejected and there is an interaction between teaching strategies and students' level of interest to teach writing. Thus, it can be concluded that the effectiveness of teaching strategies is influenced by students' level of interest.

Having analyzed the variance, further analysis done by the researcher is Tukey's 
HSD (Honest Significance Difference) Test. Tukey test is a statistical procedure used to clary which groups among the sample in specific (between the cells) have significant differences. Table 4. depicts the result of Tukey' HSD Test.

Table 4. The Summary of Tukey's HSD Test

\begin{tabular}{cccccc}
\hline Data & Sample & $\begin{array}{c}\text { Error } \\
\text { Variance }\end{array}$ & $\mathrm{q}_{\mathrm{o}}$ & $\mathrm{q}_{\mathrm{t}(.05)}$ & Status \\
\hline $\mathbf{A}_{1}$ and $\mathbf{A}_{2}$ & 26 & 1.003 & 2.99 & 2.89 & Significant \\
\hline $\mathbf{B}_{1}$ and $\mathbf{B}_{2}$ & 26 & 1.003 & 4.22 & 2.89 & Significant \\
\hline $\mathbf{A}_{1} \mathbf{B}_{1}$ and $\mathbf{A}_{2} \mathbf{B}_{1}$ & 13 & 1.418 & 4.34 & 3.06 & Significant \\
\hline $\mathbf{A}_{1} \mathbf{B}_{2}$ and $\mathbf{A}_{2} \mathbf{B}_{2}$ & 13 & 1.418 & 0.11 & 3.06 & Not Significant \\
\hline
\end{tabular}

Referring to the table, the interpretations are:

a) Because $\mathrm{q}_{\mathrm{o}}>\mathrm{q}_{\mathrm{t}}(.05)$ or $\mathrm{q}_{\mathrm{o}}$ (2.99) is higher than $\mathrm{q}_{\mathrm{t}}(.05)$ (2.89), using picture word inductive model differs significantly from controlled-writing strategy to teach writing. Regarding the mean score, the mean of A1 (78.15) is higher than the mean of A2 (75.15). Thus, the conclusion that can be drawn is that PWIM is more effective than CWS to teach writing.

b) Considering that $\mathrm{q}_{\mathrm{o}}>\mathrm{q}_{\mathrm{t}}(.05)$ or $\mathrm{q}_{\mathrm{o}}$ (4.22) is higher than $\mathrm{q}_{\mathrm{t}}(.05)$ (2.89), it can be concluded that there is a significant difference on the students' writing skill between those who have high interest and those who have low interest. Turning back to the mean score table, the mean of B1 (78.77) is higher than B2 (74.54) which means that the students having high interest have better writing skill than those having low interest.

c) Due to the fact that $q_{o}>q_{t}(.05)$ or $q_{o}$ (4.34) is higher than $q_{t}(.05)$ (3.06), it means that picture word inductive model is significantly different from controlled-writing strategy to teach writing to the students who have high interest. The mean score of $\mathrm{A}_{1} \mathrm{~B}_{1}$ (81.85) is higher than the mean score of $\mathrm{A}_{2} \mathrm{~B}_{1}$ (75.69). It can be synthesized that picture word inductive model is more effective than controlled-writing strategy to teach writing to students who have high interest.

d) Having the fact that $\mathrm{q}_{\mathrm{o}}<\mathrm{q}_{\mathrm{t}}(.05)$ or $\mathrm{q}_{\mathrm{o}}(0.11)$ is lower than $\mathrm{q}_{\mathrm{t}}(.05)$ (3.06), it is undeniable that using picture word inductive model does not differ significantly from controlled-writing strategy to teach writing to the students who have low interest. To put more simply, PWIM is as effective as CWS to teach writing for students having low interest.

\section{Discussion}

Referring to the above analysis, the findings yield that PWIM strategy is more effective than Controlled-Writing Strategy (CWS) to teach writing. This research result is in line with the research conclusion of Besral\& Indah (2015) stating that after using Picture Word Inductive Model (PWIM) strategy in experimental class in several 
meetings, the students got much more improvements in writing ability than conventional strategy in the same meeting in control class. Statistically calculated, this research result yields that the mean score of students taught by using PWIM is higher than that of students taught by using CWS. This provokes the conclusion that PWIM remarkably improves the students' writing skill. This supports the findings from Novia (2015) revealing that there was a significant difference in writing achievement between students who were taught by using PWIM and those who were not because by using PWIM, the fact that students could develop their writing achievement because they used familiar picture to brainstorm the ideas and information is inevitably true.

Essentially, the findings also support and confirm the viewpoint from McDonald (2010), arguing that PWIM provides an opportunity to incorporate language, arts, grammar and writing lesson with non-fiction areas of study. Furthermore, through this strategy, the teacher uses the generated vocabulary to lead students into inquiring about words, studying word properties (discovering structural principles), composing sentences and writing paragraphs. This is equivalent to the idea from Swartzendruber (2007), arguing that this process essentially created a picture-word dictionary in which the students could employ to connect words with corresponding pictures. Meanwhile, it is also known that the students who have high interest have better writing skill than those who have low interest. This is based on the idea that students who have a high interest will manifest strong willingness in learning; what is more, they tend to be more active during teaching and learning process. Research on writing and interests indicates that students who have an interest are more likely to set effective goals, make use of helpful strategies, and seek feedback as they work with writing task (Lipstein\&Renninger, 2015).

Primarily, interest is infectious in writing activity because the more passion the teacher brings with a topic or into the classroom, the more students want to hear about it. They begin to manifest their attention to it; as a result, their understanding in writing itself is much better. It is supported by the view from Huang \& Lin (2016), asserting that students with a high interest in learning show deeper understanding in the classroom.

Conversely, students having low interest are less keen and not invested in learning, and not as likely to be engaged. Turning back to the findings of the study, students with low interest obtained lower mean score than those who have high interest. Students who did not show any interest in English will find it difficult in understanding the lesson and confronting the challenging activities; under this circumstance, they do not show any satisfying outcome. This confirms the idea from Wimolmas (2013) who pinpoints about learning situation, students who are lack of interest tend to lose their attention, misbehave and cause discipline problems. Additionally, they tend to have less active thinking and have no willingness to solve the barriers to learning. As a result, they will become demotivated and have no enthusiastic in accomplishing the 
task.

\section{Conclusions}

After discussing the result of the study on how to determine the effectiveness of picture word inductive model to teach writing viewed from students' interest, it can be summed up: (1) There is a significant difference of students' writing skill between students who are taught by using picture word inductive model and those who are taught by using controlled-writing strategy. Picture word inductive model is more effective than controlled-writing strategy to teach writing; (2) Students having high interest have better writing skill than those who have low interest. (3) There is an interaction effect between the two variables, the strategies of teaching and the level of interest on students' writing skill.

Considering the above conclusions, there are certain suggestions. First and foremost, teacher should implement PWIM to teach English as a foreign language because it can make the classroom more dynamic, gaining students' attention, and increasing their interest. Furthermore, in choosing the picture for class, the richness of the picture in PWIM should be taken into consideration because the more contents are available in picture, the more students can develop their thinking and ideas to create sentences. In addition to this, during the implementation of PWIM, the students should manifest attention, extra effort and active involvement to be successful learners. Moreover, students should increase interest in learning English as a foreign language. They must be more confident with themselves and abandon the thought of writing is difficult; what is more, they should ease their boredom during writing lesson. All in all, this research can be used as a reference for other researchers to conduct future research dealing with a similar area of study and different psychological aspects instead of interest.

\section{References}

[1] Besral\& Indah, N. W. (2015). The use of Picture Word Inductive Model (PWIM) in the Teaching and Learning Process of Writing. Research in English Language Teaching Journal, 1(1), 29-36.

[2] Bayraktar, Aysegul. (2012). Teaching writing through teacher-student writing conferences. Social Behavorial Sciences, 51, 709-713. doi:10.1016/j.sbspro.2012.08.229

[3] Brown, H. D. (2004). Language Assessment principles and Classroom Practice.White Plains, NY: Pearson Education, Inc.

[4] Calhoun, E. F. (1999). Teaching Beginning Reading and Writing with The Picture Word Inductive Model. Alexandria, Virginia USA: Association for Supervision and Curriculum Development.

[5] Cohen, L., Manion, L., \& Morrison, K. (2007). Research methods in education (6 $6^{\text {th }}$ ed.). New York: Taylor \& Francis e-Library.

[6] Elliot, S. N., Kratochwill, T. R., Cook, J. L., et al., (2000). Educational psychology; effective teaching, effective learning. Singapore: McGraw-Hill book Co.

[7] Gall, Meredith D., Gall, Joyce P. \& Borg, Walter R. (2003). Educational Research. Boston: Pearson Education, Inc. 
[8] Harmer, Jeremy. (2004). How to Teach Writing. Edinburg gate: Pearson Education.

[9] Huang, Yu-Chen., \& Lin, Shu-Hui. (2016). Examining charisma in relation to students' interest in learning. Sage Journal, 17(2), 139-151. https://doi.org/10.1177/1469787416637481

[10] Lipstein, Rebecca L., \&Renninger, K. Ann. (2015). Interest for writing: How teachers can make a difference. The English Journal, 96(4), 79-85.

doi: $10.2307 / 30047170$

[11] McDonald, A. K. (2010). The Picture Word Inductive Model:An effective model for vocabulary instruction. The University of British Columbia.

[12] Novia, Fitri. (2015). Promoting Picture Word Inductive Model (PWIM) to Develop Students' Writing Skill. Premise Journal, 4(1). doi: http://dx.doi.org/10.24127/pj.v4i1.283

[13] Phillips, D. C., \&Burbules, N. C. (2000). Postpositivism and educationalresearch. Lanham, MD: Rowman \& Littlefield.

[14] Raimes, A. (1983). Techniques in teaching writing. New York \& Oxford: Oxford University Press.

[15] Richard, J. C, and Renandya, W. A. (2002). Methodology in language teaching. New York: Cambridge University Press.

[16] Silva, T. (1990). Second language composition instruction: Developments, issues, and directions in ESL. In B. Kroll (Eds.), Second language writing: Insights for the classroom. Cambridge: Cambridge University Press.

[17] Swartzendruber, Kara. (2007). The Picture Word Inductive Model and Vocabulary Acquisition. Proceedings of the $3^{\text {rd }}$ Annual GRASP Symposium. Wichita State University.

[18] Taylor, B. P. (1981). Content and written form: A two-way street. TESOL Quarterly, 15(1), 5-13.

[19] Wood, K. D. \&Tinajero, J. (2002). Research into Practice: Using Pictures to Teach Content to Second Language Learners. Middle School Journal, 33(5), 47-51.

[20] Wimolmas, R. (2013). A survey study of motivation in English language learning of first year undergraduate students at Sirindhorn International Institute of Technology (SIIT), Thammasat University. Proceedings ofthe 3rd International Conference on Foreign Language Learning and Teaching 2013 (FLLT 2013), "Research, Renovation and Reinforcement: Enhancing Quality in Language Education". Bangkok, Thailand.

[21] Zhao, Yu. (2014). How to Arouse the Students' Learning Interest in Foreign Language Teaching: International Conference on Education, Management and Computing Technology (ICEMCT 2014). China: Atlantis Press. 